\title{
Modelling and Control of Collecting Solar Energy for Heating Houses in Norway
}

\author{
Mehran Dehghan*1, Carlos Pfeiffer ${ }^{2}$ \\ ${ }^{1}$ Institutt for Elektro, IT og kybernetikk, University College of Southeast Norway, \\ Porsgrunn N3901, Norway \\ e-mail: mehran_dehghan2000@yahoo.com \\ ${ }^{2}$ Institutt for Elektro, IT og kybernetikk, University College of Southeast Norway, \\ Porsgrunn N3901, Norway \\ e-mail: carlos.pfeiffer@hit.no
}

Cite as: Dehghan, M., Pfeiffer, C., Modelling and Control of Collecting Solar Energy for Heating Houses in Norway, J. sustain. dev. energy water environ. syst., 5(3), pp 359-376, 2017, DOI: http://dx.doi.org/10.13044/j.sdewes.d5.0147

\begin{abstract}
In this research, a new model was developed and modified with a combined solar heating system which works with solar radiation and electricity. In order to model the system, the outdoor temperature of the location and solar irradiance has been considered. The case study of this research has been done in Porsgrunn City in the south of Norway. The building which was modelled in this research is a passive solar building which is able to store heat by using phase change materials, which are mounted on the floor and release the heat when the temperature of the house decreases. The model of the house was designed based on some assumptions about ambient temperature, solar collector size, transmitting lines length and some specific properties like air density and specific heat. The results of this research show that a solar heating system which is working with electricity can provide a sufficient temperature for the house in winter time. With using the phase change materials in order to have a passive solar building design, an improvement in the temperature inside the house was seen. Based on the simulation results which were achieved, a solar heating system which works with electricity can be an efficient system to heat the house, especially in the winter times.
\end{abstract}

\section{KEYWORDS}

Solar irradiance, Passive building, Temperature, Heat storage, Phase change material, P-controller.

\section{INTRODUCTION}

By looking at the statistics about the greenhouse effect and decreasing number of oil and gas resources, it shows renewable energy sources will play the main role in our daily life in the near future. By using solar systems, it is possible to reduce electricity consumption, and consequently our dependency on the fossil fuels will be decreased. On the other hand, using solar systems helps us to have access to clean and less polluted energy sources. Several researches have been done to model, design and compare solar thermal systems in a passive or active house for primary heat suppliers or auxiliary sources.

\footnotetext{
${ }^{*}$ Corresponding author
} 
Another research which was done in Tongji University shows the soil heat storage technology is able to store solar energy in the soil under a green house and use that energy to reduce energy demand of extreme cold and consecutive overcast weather in winter. In such systems, the heat pumps is eliminated and therefore cost is considerably reduced. After the tests, the system indicates that Seasonal Thermal Energy Storage (STES) is feasible and practical and it can partially solve the solar heat demands and supply imbalance problem between summer and winter [1].

Rekstad et al. [2] compared the energy conversion in two passive houses, the first one being a solar thermal heating and the second one, an air-to-water heat pump. The auxiliary energy demand in the solar heated house, the first system's efficiency is $15-20 \%$ lower than for the system heated by air-to-water heat pump. It was reported that system costs of both heating technologies were approximately equal. It was concluded that solar heating is competitive from an economical and performance point of view even for the Nordic and cold climates.

There was an evaluation of solar hot water heating system application in South Korea for a period of three years. In this research [3], a solar hot water heating system installed in a multi-family housing complex with 1,179 households in 14 units. It was shown that compared to the conventional boiler $(\delta=85 \%)$, the system brought a positive environmental effect equivalent to 71,907 L/year (Liter per year) of oil reduction, and reduction of $50.8 \mathrm{t} \mathrm{C}$ (tonnes of Carbon) and $186.3 \mathrm{t} \mathrm{CO}_{2}$ (tonnes of Carbon dioxide). Mori \& Kawamura [4] had discussed a new design of solar water heating system in the severe cold region at middle latitude. In this research, solar water heating system combined with heat-pump system was introduced and analysed by numerical methods.

In terms of $\mathrm{CO}_{2}$ emissions a net energy analysis of a solar system combined with seasonal Thermal Energy Store was done in University of Ulster and it illustrates how a low-energy building has achieved nearly zero energy heating through the combined system which works with a solar domestic hot water and space heating system and a seasonal Thermal Energy Store. Based on the research it has been concluded that use of both solar thermal and solar photovoltaic energy can be attractive in order to reduce carbon emissions and improve life cycle energy consumption in the long term [5].

The measurement results indicate that the percentage of solar energy in the total hot water supply is about $20 \%$ during the severe cold period. It was also mentioned that in the severe cold area, existing solar hot water heating is not so effective because the heat loss from the panel is higher than another area. Fraga et al. [6] made an in-situ monitoring of large solar assisted heat pump systems in collective houses in Switzerland. In this research, a new complex house with a modern system is provided. It consists of a system coupling solar collectors and heat pumps to provide space heating and domestic hot water. Direct solar fraction during the summer period is lower than $50 \%$. A higher value was expected, considering the oversizing of collector field for domestic hot water production. Total observations showed a real potential in summer times but not as was expected.

Another research which has been done in Canada, is solar assisted space heating of an extremely insulated energy efficient house in which a solar powered house has been designed and it has focused on vacuum tube collectors over the flat plate collectors which show that, by using an under-the-floor radiant heating system, energy consumption is reduced to $8 \%$ of the consumption for the case when the in-floor system is not utilized [7].

Several other researches only made a simulation of solar heating systems. As an example, Badescu [8] simulated an active solar heating system in a passive house. The model included a solar thermal collector area, a water storage tank, a secondary water circuit, a Domestic Hot Water (DHW) preparation system and an air ventilation/heating 
system. Two different series interconnection schemes were analysed for the water-to-air and water-to-water heat exchangers. The main conclusion was that the series interconnection is unfavourable for the water-to-air heat exchanger.

In another investigation, Ampatzi et al. [9] made an investigation of solar energy harvesting potential by active water-based systems including heat storage in houses in Northern Europe. It was concluded that solar energy could take a part as auxiliary source along with conventional energy which is consumed for heating and domestic hot water preparation in existing residences in the north of Europe. In addition, more than $34 \%$ solar contribution could be possible by immediate use of the absorbed energy if the energy demand and energy access are well matched. It was also shown that uncommonly large collector areas could significantly increase usability in the local houses in this area and it would be around 50\% solar contribution with small store sizes.

Besides using a solar thermal or electrical system, many researchers tried using a hybrid system which could improve the efficiency of the system and minimize auxiliary sources. For example, Tamvakidis et al. [10] evaluated a hybrid solar heating system for a duration of eight months. The system consisted of a roof solar collector, a solar mass wall, a heat storage tank, a heat supply tank and a specially designed creep heating slatted floor. The experiment's results showed that $70 \%$ of the essential heating was supplied in the warm period of the year, while in the cold sessions it was about 25-30\%. It was also found, in order to have an improved performance during the day time a larger hating storage is needed.

Ahmad et al. [11] investigated energy savings in houses by using an innovative solar thermal collector combined with a heat pump system. The purpose of this research was to maintain comfort temperature inside the house and reduce the electricity consumption used for heating and hot water. In some projects and researches the models of the conventional on-off controller and a multi-variable model predictive control were developed and used for several different climatic conditions. The results showed that the model predictive control controller illustrated to maintain better thermal comfort and lower temperature fluctuation as well as saving over $9 \%$ energy use.

In terms of heat storage systems a combined hybrid heating-system which has been combined with phase change material plates as thermal storage systems was done in Tsinghua University [12]. This research considered a direct passive solar building which consists of Phase Change Material (PCM) plates as the inner lining of walls and the ceiling. An additional heat supply is included during load hours at late night and early morning or when the solar radiations are in the minimum level to keep the space temperature of the house above $18{ }^{\circ} \mathrm{C}$. The results indicate an improvement in the indoor thermal comfort level and around 47\% energy is saved during normal and peak hour energy and $12 \%$ of total energy consumption is saved in the winter. Kensby et al. [13] presented results of a short thermal energy storage functionalities and possibilities for five multifamily residential buildings in Gothenburg, Sweden. In another experiment, a heating system was employed to regulate the temperatures of a specific building. It was using a photovoltaic field to feed a heat pump. It was seen that the Photovoltaic (PV) system cannot supply heat enough to maintain the proper inner conditions: it would be necessary to feed the heat pump partially through grid electricity [14].

The term passive solar building design is used for a house in which, windows, walls and floors have been made to collect, store and distribute solar energy in the form of heat. It is called a passive system because it does not use mechanical and electrical devices in comparison with an active heating system. One of the goals to design and use passive solar buildings is to take advantage of the local weather [15]. There have been many approaches using solar energy in order to fulfil low energy and passive buildings. 
Photovoltaic and solar thermal energies could be simultaneously used in order to achieve an optimized solution for this situation. Kumar and Rosen [16] reviewed Photovoltaic-solar Thermal (PV/T) collectors for air heating and recent advances. The potential of PV/T collectors has been recognized for many decades and has received enlarged consideration in the past years. It has been shown that using solar system and technologies to provide heat and electricity seperately is often recognised as more affordable. In this research the main focus is using phase change material as thermal energy storage. Using Thermal Energy Storage (TES) the dependence on fossil fuels and electricity could be reduced in heat usage. The best method of using TES in a building involves sensible heat storage by changing the temperature of a storage material. One of the effective ways to have a passive system and reduce energy consumption is using PCM in passive Latent Heat Thermal Energy Storage (LHTES) system of building's wall, floor and windows. PCMs can be used as thermal energy storage, and the principle of using them is simple [17]. Another research which has been used PCM as a heat source in winter was done in university of Negev. The research shows how phase change materials could be installed under the floor and uses the electricity in order to melt PCM during the night and release the heat into the space above the floor during the day time. There is also an electrical power to preserve thermal comfort in the house [18].

In this research, it is tried to model and analyze a phase change from solid to liquid and vice versa. Each phase change material is a latent thermal storage material and has a specific melting/solidification point. Before the temperature reaches the melting point, the temperature of PCM increases. After reaching the temperature of the melting point, melting process begins and it is continues until all of the PCM becomes liquid. While PCM is melting, the temperature remains constant (melting point). When PCM is totally a liquid mass, the temperature is increases further. By decreasing the ambient temperature to below solidification point, freezing or solidification process begins. While PCM solidifies, the temperature is constant at the solidification point and when PCM is totally a solid mass, temperature starts decreasing. PCM's temperature is increased as it absorbs heat. When the PCM has reached the melting point, the PCM will absorb a large amount of heat without getting hotter and the reverse process occurs when the ambient temperature is decreased and PCM's temperature reaches the solidification point and releases its stored latent heat, so it can be concluded PCM absorbs and releases heat while having a constant temperature [19]. In this research, phase change material has been located under the floor and between the water coils then heat transfer is done easily, and heat loss is reduced as less as possible. The material which has been considered for this research is Manganese nitrate + Manganese chloride $\left[\mathrm{Mn}\left(\mathrm{NO}_{3}\right) 2.6 \mathrm{H}_{2} \mathrm{O}+\mathrm{MnCl} 2.4\right.$ $\mathrm{H}_{2} \mathrm{O}$ ] which is an inorganic PCM with melting point of $15-25^{\circ} \mathrm{C}$ and fusion heat of $125.9 \mathrm{~kJ} / \mathrm{kg}[20]$.

This paper presents a combined solar system which has been modelled in a passive building and for the simulation part different assumptions like solar radiation, ambient temperature, air mass, specific heat capacities, heat transfer coefficients and PCM's melting point have been considered. Although there are several researches in Nordic zone which are related to this topic, in this research it was tried to use different scenarios and assumptions in order to have a clear comparison and accurate result. The main goal is having a comfort temperature in the house during the cold period. Phase change materials have been located in the floor to improve the temperature of the house during the night time and an electrical boiler has been used to heat up the water inside the tank when there is no radiation and solar system is not able to raise the water's temperature to the required level. This system is called a near zero building which uses renewable energy sources to heat the house and reduces fossil fuel consumption. 


\section{MATERIALS AND METHODS}

In order to have a broad view of the model which has been used in this research some important parameters like outdoor temperature, solar irradiance, etc., must be considered.

\section{Outdoor temperature}

The introduced model of the house can be used for any location with different climates, but in this research most of the parameters like the temperature, sun irradiance, etc., have been measured in Porsgrunn, which is located in south east Norway. One of the important parameters to use a solar system is estimating ambient temperature based on the location where a solar heating system is supposed to be installed. Figure 1 illustrates average temperature of Porsgrunn from July 2013 to April 2014 based on year wise database, which is the main weather forecast website in Norway. The goal of this research is heating the houses in the cold seasons, so weather database has not been collected for the summer time and just nine months have been considered for the simulation data.

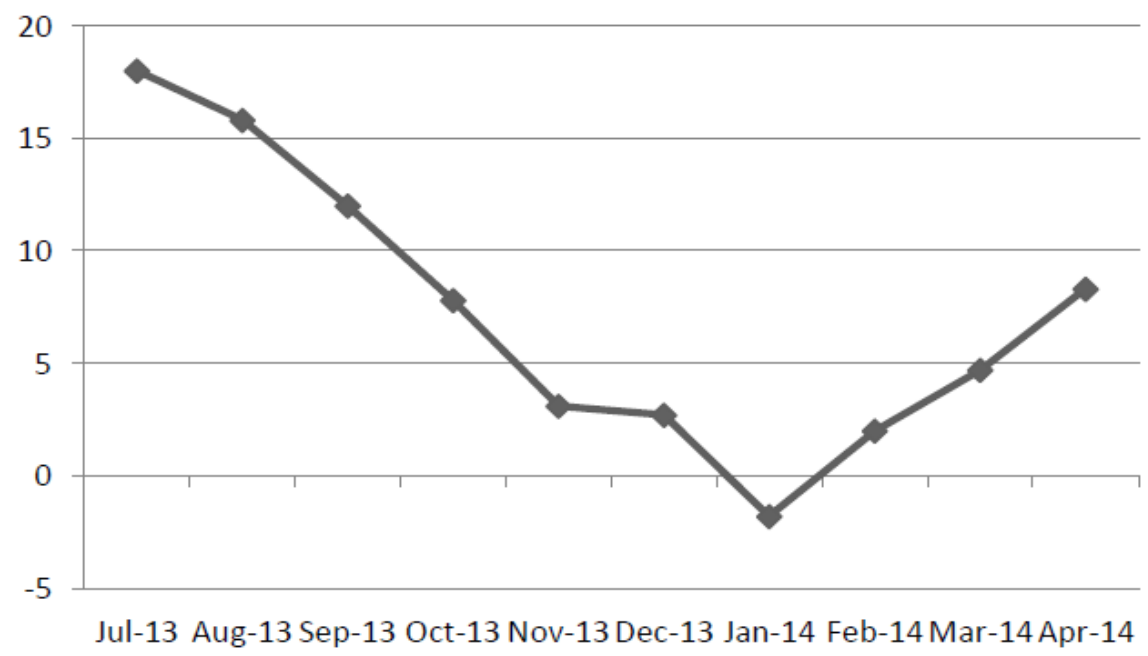

Figure 1. Average temperature of Porsgrunn for 9 months (y-axis shows the temperature in degrees Celsius)

Based on data from Figure 1, the mean temperature between October and April is less than $10^{\circ} \mathrm{C}$ and this is the period in which houses need more energy to be heated and reach the convenient inside temperature for living. In this research, the goal is to reach the indoor temperature of $20{ }^{\circ} \mathrm{C}$ to $25^{\circ} \mathrm{C}$ by using a solar system which is combined with electricity.

\section{Solar irradiance}

One of the most important parameters which plays a primary role for using a solar heating system is solar irradiance. The solar irradiance is a power of sun in the form of electromagnetic waves per unit area on the Earth's surface and normally it is measured in the units of kilowatt per square meter $\left(\mathrm{kW} / \mathrm{m}^{2}\right)$ [21]. In this research, a designed sensor has been used which is able to measure sun radiation to an accuracy of $0.2 \%$ and we try to use measured radiation values for the simulations part [22].

\section{MODEL OF THE HOUSE}

The main principle of this system is using sun irradiance and electricity coils to heat the water and add to the storage tank. When the house needs heat, the hot water inside the 
tank is circulated through the under floor tubes and this cycle maintains the indoor temperature at a stable level. In this research, water is the medium which has been considered to absorb the heat and transmit it to the air. There is a water tank used as the heat storage, and it has a fixed water level. An electrical element (boiler) is added to the storage in order to help water to heat up faster. The boiler is considered to support the system when there is not much sun irradiance and the temperature of the water inside the tank decreases. There are two piping systems in this project, one of them is the collector piping which is inside the water tank and it is used to circulate the water through it and warm the water by absorbing heat from the solar collectors and another one is the piping system which goes through under the floor and is responsible to heat up the house. Figure 2 shows a simple solar system which has been used in this research.

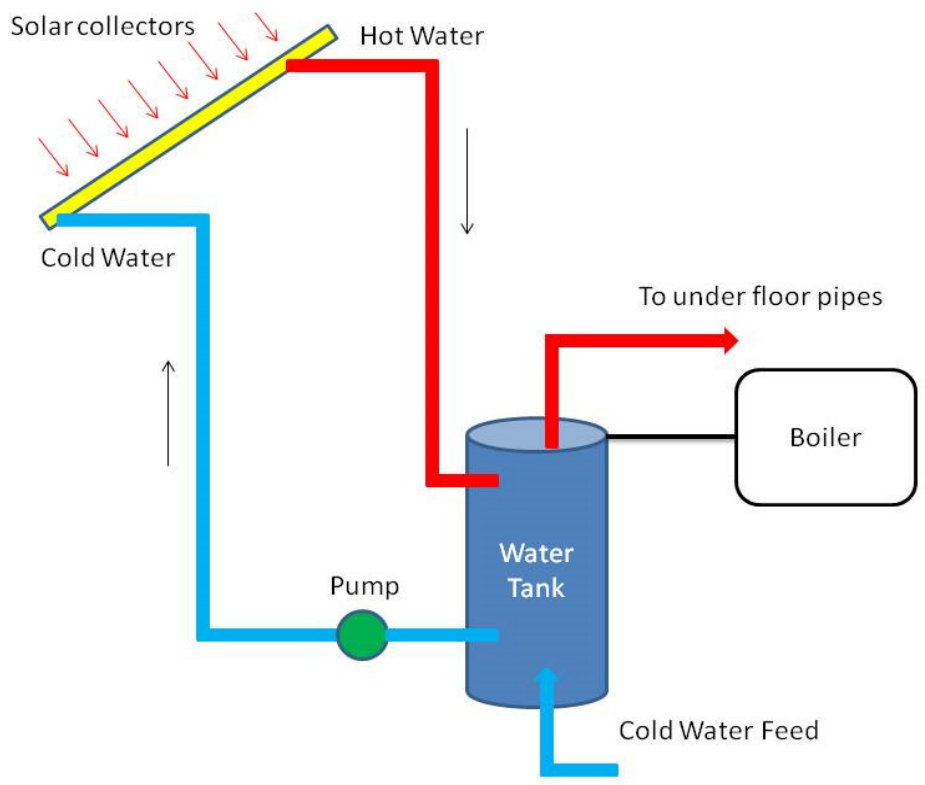

Figure 2. A simple solar heating system with different parts

\section{Solar collector}

Solar collectors are installed to collect the sun irradiance and use it for heating the water; it is possible to harness the energy from the sun and convert it to heat by using the Solar Thermal (ST) technology. In this research, a solar collector is used as a magnifying glass which directs solar irradiance to the absorber pipes. The important factor is the ability of the glass envelop to absorb a greater portion of the sun's spectrum [23]. As mentioned, there is a piping system to push water through the solar collector in order to heat it up and transfer it to the water tank. One of the important parameters to have a better heating transfer from the absorber pipes to the fluid with a low percentage of loss is to choose a material with high thermal conductivity, such as copper. Here the considered fluid is water and by considering copper as the pipe material, a heat transfer coefficient of $340-455 \mathrm{~W} / \mathrm{m}^{2} \mathrm{~K}$ is reached between the absorber pipes and the fluid (water).

Solar collector model. In order to model the solar collector, each part must be considered. In this research, a solar collector consists of a flat plate, the absorbing medium and the glass envelope. Figure 3 shows a scheme of a flat plate of the solar collectors with different parts. The main equation used to model the temperature of various regions of the system is the energy balance equation. The models are developed for the temperature of each element in the system. Eq. (1) illustrates general energy balance model, where $\dot{H}_{i}$ is related to the input mass, $\dot{H}_{o}$ is related to the output mass, $\dot{W}_{s}$ is the shaft work, and $\dot{Q}$ is the amount of heat inside the model. There is no shaft work 
transfer. The terms in eq. (2) are heat transfer from the wooden floor and PCM, heat loss through the wall, and possible heat gain from any external sources:

$$
\begin{gathered}
d H / d t=\dot{H}_{i}-\dot{H}_{o}+\dot{Q}+\dot{W}_{s} \\
\dot{Q}=h_{c f-h} A_{f}+h_{c p c m-h} A_{f}-h_{c h-o} A_{h-o}+\dot{Q}_{e h}
\end{gathered}
$$

As an assumption in the whole system, it is considered that $\dot{H}_{i}=0$ and $\dot{H}_{o}=0$ since there is no bulk mass movement of material across the system and $\dot{W}_{s}=0$, since there is no shaft work transfer.

Based on the solar collector scheme, it is possible to find out the glass envelop temperature, the absorber medium (water) temperature and also the collector plate temperature. However, since the goal of this research is studying the final temperature of the house and the absorber medium plays a primary role in heating up the house, the other models are neglected and here the focus is on finding the water temperature inside the pipes located under the glass envelope. Eq. (3) shows the final model to determine the temperature of the water inside the collector pipes:

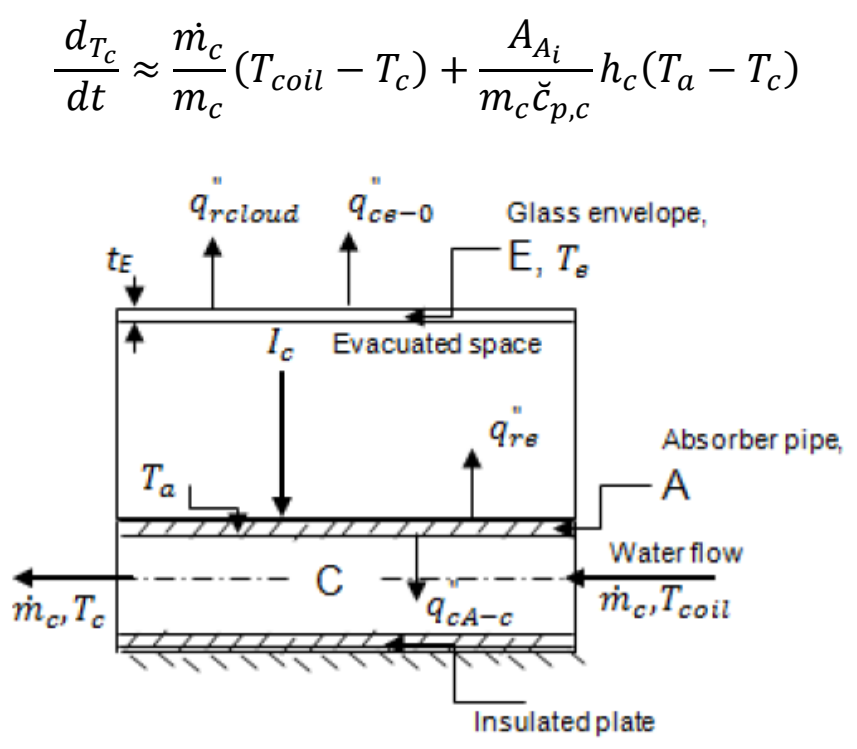

Figure 3. Sectional view of a flat plate solar collector

\section{Water tank}

As seen in Figure 2, there is a water tank in the solar heating system, which is responsible to store the water for heating. In this research, water has a fixed level in the tank, and it is passed through the absorber pipes and the floor tubes. There are two different piping systems in the tank. The first one is the absorber pipes which go to the solar collectors. The water is circulated through them to gain heat and subsequently heat up the water in the tank. The second piping system is related to the floor tubes. It directs warmed water to the floor of the house. Water is pumped continuously through absorber pipes and the floor tubes. An electrical boiler is responsible for heating the water inside the tank when there is not enough sun radiation to keep the water warm at a particular temperature.

Storage tank model. In order to model the storage tank, different parts of it should be considered. In this research, a storage tank consists of the tank's heating coil (boiler), the transmitting coil model and the water tank model. Figure 4 shows a scheme of the storage tank with different parts of it. 


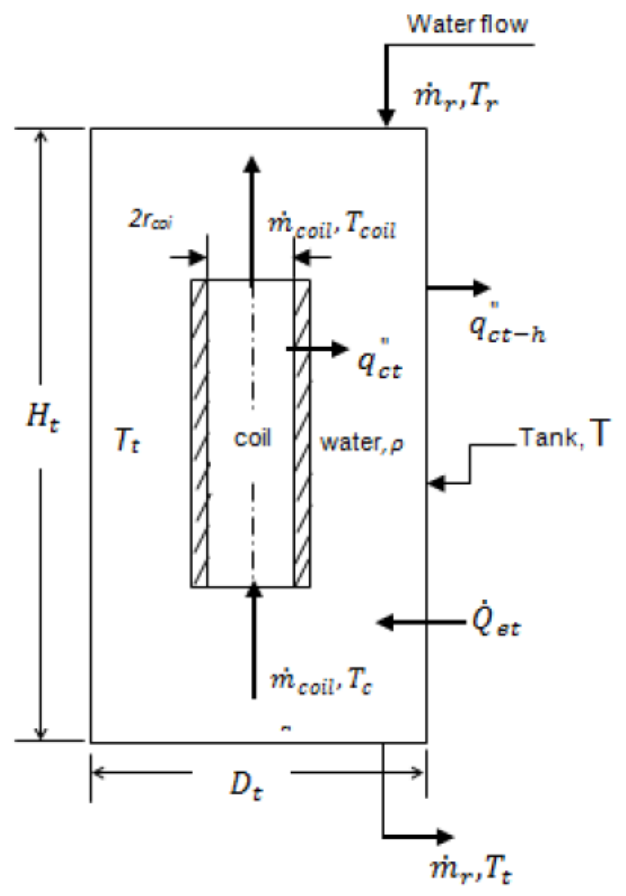

Figure 4. Scheme of storage tank with different parts and parameters

By using energy balance, eq. (4) is obtained for the temperature of water inside the tank:

$$
\frac{d_{T_{t}}}{d t} \approx \frac{\dot{m}_{r}}{m_{t}}\left(T_{r}-T_{t}\right)+\frac{A_{c o i l, i}}{m_{t} \breve{c}_{p, t}} U_{c o i l-T}\left(T_{c o i l}-T_{t}\right)-\frac{A_{t-h}}{m_{t} \breve{c}_{p, t}} U_{t-h}\left(T_{t}-T_{h}\right)+\frac{\dot{Q}_{e t}}{m_{t} \breve{c}_{p, t}}
$$

\section{Floor tubes (coils)}

In this research, the under-floor heating system consists of two parts which are used together for space warming of the house. The first one is under-floor tubes and the second one is phase change materials. Here, the size of the room has been considered as $164 \mathrm{~m}^{3}$ and the area of the house floor is $64 \mathrm{~m}^{2}$. It means the height of the room is around 2.56 meters, which is acceptable for a normal sized house. Phase change materials are mounted between the tubes and close to the floor. The maximum temperature for under floor heating system is considered $300 \mathrm{~K}\left(26.86^{\circ} \mathrm{C}\right)$. To have a more isolated system and save more heated air in the house, a wooden floor with a low level of heat conductivity is considered.

Floor models. A floor model consists of an underground heating coil, wooden floor and PCM model. Figure 5 shows a scheme of the floor with its different parts.

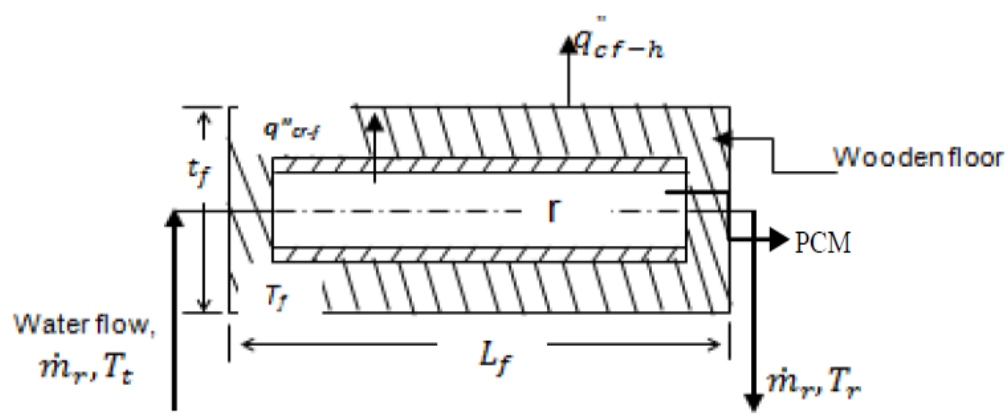

Figure 5. Scheme of floor with different parts and parameters 
As mentioned, three models must be considered for the floor. The first model is the underground heating coil. By assuming that the wooden floor is compact and the space between the heating coils and the wooden floor is empty, and by neglecting the thickness of the coil wall, a final model for the temperature of under floor pipes can be found. Eq. (5) shows the model of the underground heating coil in terms of temperature and based on energy balance:

$$
\frac{d_{T_{r}}}{d t}=\frac{\dot{m}_{r}}{m_{t}}\left(T_{t}-T_{r}\right)-\frac{A_{r, i}}{m_{r} \breve{c}_{p, r}} h_{r}\left(T_{r}-T_{f}\right)
$$

According to Figure 5, a phase change material has been located between underground coils to improve the heating of the house. In this case, there is a heat exchange between PCM and floor and also a heat exchange between PCM and the house. By considering an insulated system, it is assumed that there is no heat exchange between PCM and the underground coils. Thus the temperature of PCM would be:

$$
q_{\text {in }}=q_{\text {out }}=h_{p c m} A_{f}\left(T_{f}-T_{p c m}\right)
$$

By considering heat loss and heat gains for the floor, eq. (7) shows the final model of the temperature of the floor. Table 1 and Table 2 present the parameters for calculating heat losses in the system:

$$
\frac{d_{T_{f}}}{d t} \approx \frac{A_{r, i}}{m_{f} \breve{c}_{p, f}} h_{r}\left(T_{r}-T_{f}\right)-\frac{A_{f}}{m_{f} \breve{c}_{p, f}} U_{f-h}\left(T_{f}-T_{h}\right)-\frac{A_{f}}{m_{f} \breve{c}_{p, f}} U_{p c m}\left(T_{f}-T_{p c m}\right)
$$

\begin{tabular}{|c|c|}
\hline \multicolumn{2}{|r|}{ Model nomenclatures } \\
\hline$A_{A_{i}}$ & Inner surface area of the collector plate \\
\hline$A_{\text {coili,i }}$ & Inner area of the tank's heating coil \\
\hline$A_{f}$ & Area of the house floor \\
\hline$A_{h-o}$ & Area between the house and the environment \\
\hline$A_{r, i}$ & Section area of underground heating coil \\
\hline$\breve{c}_{p, c}$ & Specific heat capacity of water in the absorber pipes \\
\hline$\breve{c}_{p, f}$ & Specific heat capacity of the wooden floor \\
\hline$\breve{c}_{p, h}$ & Specific heat capacity of air in the house \\
\hline$\breve{c}_{p, t}$ & Specific heat capacity of water in the absorber pipes \\
\hline$h_{c}$ & Heat transfer coefficient between the absorbing pipe and the absorbing fluid \\
\hline$h_{p c m}$ & Heat transfer coefficient of the PCM \\
\hline$h_{r}$ & Heat transfer coefficient between the floor and the underground heating coil \\
\hline$m_{f}$ & Mass of the floor \\
\hline$m_{h}$ & Mass of air in the house \\
\hline$m_{r}$ & Water mass within the floor heating coil \\
\hline$m_{t}$ & Mass of water within the tank \\
\hline$\dot{Q}_{e h}$ & Possible heat gain from external source \\
\hline$\dot{Q}_{e t}$ & Possible heat gain from the electrical element (boiler) \\
\hline$T_{a}$ & Temperature of the solar heat collecting plate \\
\hline$T_{\text {coil }}$ & Temperature of water in the tank's heating coil \\
\hline$T_{f}$ & Temperature of the floor \\
\hline$T_{h}$ & Temperature of air in the house \\
\hline$T_{o}$ & Environment temperature \\
\hline$T_{p c m}$ & Temperature of PCM \\
\hline$T_{r}$ & Temperature of the water in the underground heating coil \\
\hline$T_{t}$ & Temperature of water in the tank \\
\hline$U_{f-h}$ & Overall heat transfer coefficient between the floor and house \\
\hline$U_{h-o}$ & Overall heat transfer between the house and the environment \\
\hline$U_{p c m}$ & Heat transfer coefficient between the PCM and house and temperature of PCM \\
\hline$U_{t-h}$ & Overall heat transfer coefficient between the tank and the surrounding air \\
\hline
\end{tabular}

Table 1. Model nomenclatures 
Table 2. State of the model and nomenclature

\begin{tabular}{cccc}
\hline States & Initial value & Unit & Nomenclature \\
\hline$m_{h}$ & 201.69 & {$[\mathrm{~kg}]$} & Mass of air in the house \\
$T_{h}$ & 280 & {$[\mathrm{~K}]$} & Temperature of air in the house \\
$T_{f}$ & 280 & {$[\mathrm{~K}]$} & Temperature of the floor \\
$T_{r}$ & 280 & {$[\mathrm{~K}]$} & Temperature of water in the underground heating coil \\
$T_{t}$ & 280 & {$[\mathrm{~K}]$} & Temperature of water in the tank \\
$T_{\text {coil }}$ & 280 & {$[\mathrm{~K}]$} & Temperature of water in the tank heating coil \\
$T_{c}$ & 280 & {$[\mathrm{~K}]$} & Temperature of water in the solar heat absorbing coil \\
$T_{A}$ & 280 & {$[\mathrm{~K}]$} & Temperature of the solar heat collecting plate \\
$T_{E}$ & 280 & {$[\mathrm{~K}]$} & Temperature of the collector glass envelope \\
\hline
\end{tabular}

\section{Temperature of air}

In order to obtain the temperature of the air, it is necessary to consider the model of the house. Figure 6 shows the whole model of the house.

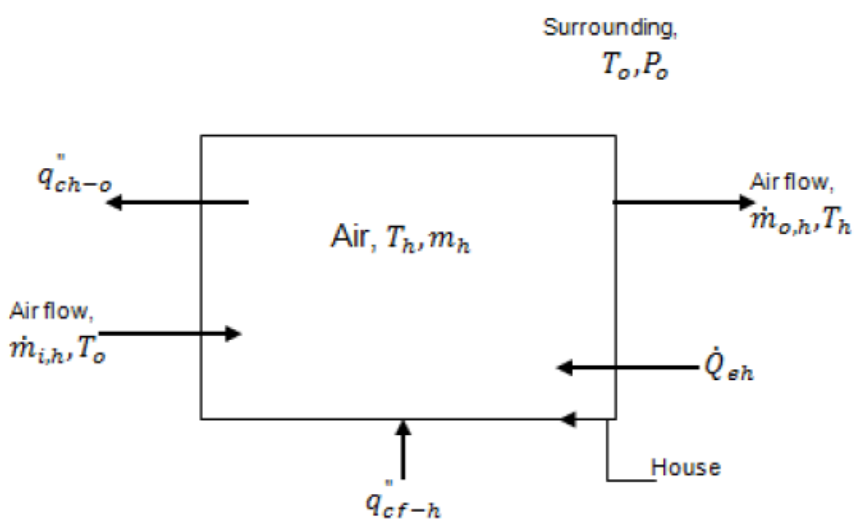

Figure 6. Scheme of model of the house with different parameters

According to Figure $6, \dot{H}_{i}=\dot{m}_{i, h} \tilde{H}_{i, h}, \dot{H}_{o}=\dot{m}_{o, h} \tilde{H}_{h}$ and $\dot{W}_{s}=0$ because there is no shaft work transfer. The heat transfer gain is from the wooden floor and PCM, the heat loss through the wall, and the possible heat gain from any external source. Eq. (8) illustrates the final model to find the temperature of the air inside the house:

$$
\frac{d_{T_{h}}}{d t} \approx \frac{\dot{m}_{i, h}}{m_{h}}\left(T_{o}-T_{h}\right)+\frac{A_{f}}{m_{h} \breve{c}_{p, h}} U_{f-h}\left(T_{f}-T_{o}\right)-\frac{A_{f}}{m_{h} \breve{c}_{p, h}} U_{p c m-h}\left(T_{p c m}-T_{h}\right)-\frac{A_{h-o}}{m_{h} \breve{c}_{p, h}} U_{h-o}\left(T_{h}-T_{o}\right)+\frac{\dot{Q}_{e h}}{m_{h} \breve{c}_{p, h}}
$$

\section{Parameters}

In order to simulate the mentioned models, having some parameters is necessary. Tables 1-4 illustrate the important parameters which have been considered in this research, along with their values.

Table 3. Parameters of the model and nomenclature

\begin{tabular}{|c|c|c|c|c|c|c|c|}
\hline Parameters & Value & Unit & Nomenclature & Parameters & Value & Unit & Nomenclature \\
\hline$\rho_{A}$ & 8,900 & {$\left[\mathrm{~kg} / \mathrm{m}^{3}\right]$} & $\begin{array}{l}\text { Density of copper used as } \\
\text { solar heat collector }\end{array}$ & $V_{h}$ & 160 & {$\left[\mathrm{~m}^{3}\right]$} & Volume of air in the house \\
\hline$C_{p, A}$ & 389 & {$[\mathrm{~J} / \mathrm{kgK}]$} & $\begin{array}{l}\text { Specific heat capacity } \\
\text { of copper }\end{array}$ & $A_{t-h}$ & 4.195 & {$\left[\mathrm{~m}^{2}\right]$} & $\begin{array}{l}\text { Total surface of the tank } \\
\text { exposed to the surrounding air }\end{array}$ \\
\hline$\sigma$ & $5.67 \times 10^{-8}$ & {$\left[\mathrm{~W} / \mathrm{m}^{2} \mathrm{~K}^{4}\right]$} & Stefan-Boltzman constant & $t_{E}$ & 0.004 & {$[\mathrm{~m}]$} & $\begin{array}{l}\text { Thickness of the } \\
\text { glass envelope }\end{array}$ \\
\hline$\varepsilon_{A}$ & 0.01 & - & Emissivity of copper & $\varepsilon_{E}$ & 0.92 & - & Emissivity of glass envelope \\
\hline$r_{A, i}$ & 0.0250 & {$[\mathrm{~m}]$} & $\begin{array}{l}\text { Inner radius of solar heat } \\
\text { absorbing coil }\end{array}$ & $n$ & 0.6 & {$[1 / \mathrm{h}]$} & $\begin{array}{c}\text { Number of air exchange rate } \\
\text { per hour }\end{array}$ \\
\hline
\end{tabular}


Table 4. Parameters of the model

\begin{tabular}{|c|c|c|c|c|c|c|c|}
\hline Parameters & Value & Unit & Nomenclature & Parameters & Value & Unit & Nomenclature \\
\hline$h_{r}$ & 2,600 & {$\left[\mathrm{~W} /\left(\mathrm{m}^{2} \mathrm{~K}\right)\right]$} & $\begin{array}{l}\text { Heat transfer coefficient between the floor } \\
\text { and the underground heating coil }\end{array}$ & $\rho_{g}$ & 2,700 & {$\left[\mathrm{~kg} / \mathrm{m}^{3}\right]$} & $\begin{array}{l}\text { Density of glass used as the } \\
\text { collector envelope }\end{array}$ \\
\hline$C_{p, r}$ & 4,180 & {$[\mathrm{~J} / \mathrm{kgK}]$} & $\begin{array}{c}\text { Specific heat capacity of water within the } \\
\text { storage tank }\end{array}$ & $C_{p, E}$ & 833 & {$[\mathrm{~J} / \mathrm{kgK}]$} & Specific heat capacity of glass \\
\hline$U_{\text {coil-T }}$ & 1,200 & {$\left[\mathrm{~W} / \mathrm{m}^{2} \mathrm{~K}\right]$} & $\begin{array}{l}\text { Overall heat transfer coefficient between } \\
\text { the tank and the heat transmitting coil }\end{array}$ & $C_{p, t}$ & 4,180 & {$[\mathrm{~J} / \mathrm{kgK}]$} & $\begin{array}{l}\text { Specific heat capacity of water in } \\
\text { the absorber pipes }\end{array}$ \\
\hline$h_{c}$ & 2,600 & {$\left[\mathrm{~W} / \mathrm{m}^{2} \mathrm{~K}\right]$} & $\begin{array}{l}\text { Heat transfer coefficient between the } \\
\text { absorbing pipe and the absorbing fluid }\end{array}$ & $h_{E \text {-cloud }}$ & 1.27 & {$\left[\mathrm{~W} / \mathrm{m}^{2} \mathrm{~K}\right]$} & $\begin{array}{l}\text { Heat transfer coefficient between } \\
\text { the glass envelope and the cloud }\end{array}$ \\
\hline$C_{p, a}$ & 1,005 & {$[\mathrm{~J} / \mathrm{kgK}]$} & Specific heat capacity of air in the house & $U_{E-o}$ & 1.27 & {$\left[\mathrm{~W} / \mathrm{m}^{2} \mathrm{~K}\right]$} & $\begin{array}{c}\text { Overall heat transfer coefficient } \\
\text { between the glass envelope } \\
\text { and air }\end{array}$ \\
\hline$C_{p, f}$ & 630 & {$[\mathrm{~J} / \mathrm{kgK}]$} & Specific heat capacity of the wooden floor & $r_{r, i}$ & 0.03 & {$[\mathrm{~m}]$} & $\begin{array}{l}\text { Inner radius of heating coil in } \\
\text { the underground floor }\end{array}$ \\
\hline$\rho_{w}$ & 1,000 & {$\left[\mathrm{~kg} / \mathrm{m}^{3}\right]$} & $\begin{array}{l}\text { Density of water used as heat } \\
\text { transmitting fluid }\end{array}$ & $B$ & 2 & {$[\mathrm{~m}]$} & Width of the collecting plate \\
\hline$L_{r}$ & 200 & {$[\mathrm{~m}]$} & Length of underground heating coil & $L_{c l}$ & 5.6 & {$[\mathrm{~m}]$} & Length of the collecting plate \\
\hline$C_{p, c}$ & 4,180 & {$[\mathrm{~J} / \mathrm{kgK}]$} & $\begin{array}{c}\text { Specific heat capacity of water in the } \\
\text { absorbing pipes }\end{array}$ & $A_{f}$ & 64 & {$\left[\mathrm{~m}^{2}\right]$} & Area of the house floor \\
\hline$L_{\text {coil }}$ & 29 & {$[\mathrm{~m}]$} & $\begin{array}{l}\text { Length of the coil transmitting heat in } \\
\text { the tank }\end{array}$ & $v_{W}$ & 2.5 & {$[\mathrm{~m} / \mathrm{s}]$} & Velocity of water in the coil \\
\hline$U_{t-h}$ & 1.71 & {$\left[\mathrm{~W} / \mathrm{m}^{2} \mathrm{~K}\right]$} & $\begin{array}{l}\text { Overall heat transfer coefficient between } \\
\text { the tank and the surrounding air }\end{array}$ & $p_{o}$ & 101,300 & {$\left[\mathrm{~N} / \mathrm{m}^{2}\right]$} & Atmospheric pressure \\
\hline$A_{t-a}$ & 4.195 & {$\left[\mathrm{~m}^{2}\right]$} & Total area of the tank exposed to air & $R$ & 287 & {$[\mathrm{~J} / \mathrm{kgK}]$} & Gas constant for air \\
\hline$A_{t}$ & 1.0 & {$\left[\mathrm{~m}^{2}\right]$} & Cross sectional area of the tank & $\rho_{f}$ & 561 & {$\left[\mathrm{~kg} / \mathrm{m}^{3}\right]$} & Density of the wooden floor \\
\hline$H_{t}$ & 0.9 & {$[\mathrm{~m}]$} & Total height of the tank & $t_{f}$ & 0.01 & {$[\mathrm{~m}]$} & $\begin{array}{l}\text { Thickness of the underground } \\
\text { wooden floor }\end{array}$ \\
\hline$L_{c}$ & 112.5 & {$[\mathrm{~m}]$} & Length of the solar absorber coil & $U_{h-o}$ & 0.15 & {$\left[\mathrm{~W} / \mathrm{m}^{2} \mathrm{~K}\right]$} & $\begin{array}{c}\text { Overall heat transfer coefficient } \\
\text { between the house and } \\
\text { outside air }\end{array}$ \\
\hline$r_{A, o}$ & 0.0252 & {$[\mathrm{~m}]$} & Outer radius of solar heat absorbing coil & $U_{f-h}$ & 2.81 & {$\left[\mathrm{~W} / \mathrm{m}^{2} \mathrm{~K}\right]$} & $\begin{array}{l}\text { Overall heat transfer coefficient } \\
\text { between the floor and house }\end{array}$ \\
\hline$r_{c, i}$ & 0.0250 & {$[\mathrm{~m}]$} & Inner radius of the tank heating coil & $\mathrm{k}$ & 50 & {$[\mathrm{~kg} / \mathrm{bar} \mathrm{s}]$} & Valve constant \\
\hline
\end{tabular}

\section{GENERAL ASSUMPTIONS}

The ambient temperature varied according to a polynomial of order 5. Ambient temperature is fitted for 48 hours based on temperature of cloudy and sunny weather conditions. These assumptions have been considered based on the year number database, which shows the average temperature of March 2014 in Porsgrunn.

As seen in Figure 7, the minimum temperature in March is around $-1{ }^{\circ} \mathrm{C}$ and the maximum temperature is around $15{ }^{\circ} \mathrm{C}$, which shows that in order to reach a comfort temperature inside the house, a combined solar heating system which works with solar radiation and electricity can be used. Here, the days considered for the simulations are $22^{\text {nd }}$ to $24^{\text {th }}$ of March.

The first day is considered as a cloudy day and the minimum temperature is $277 \mathrm{~K}$, and the maximum temperature is $279 \mathrm{~K}$ and the second day is considered as a sunny day with minimum and maximum temperatures of $279 \mathrm{~K}$ and $284 \mathrm{~K}$, respectively. Figure 8 shows the ambient temperature which has been simulated for two days.

The other assumptions which have been considered in this research are: the solar collector and transmitting lines are perfectly insulated. The specific properties like density, specific heat, etc. for each system are constant. The storage tank is placed inside the house. The oxygen from the air in the house and the added heat consumed due to human breathing are negligible. The ideal gas behaviour is assumed for the air in the house. All other external heating sources like direct sunlight, cooking, etc. are negligible. The velocity of the flow in all transmitting lines is constant. Mass flow of water through absorber pipes is constant. 
Temperature of March 2014 in Porsgrunn

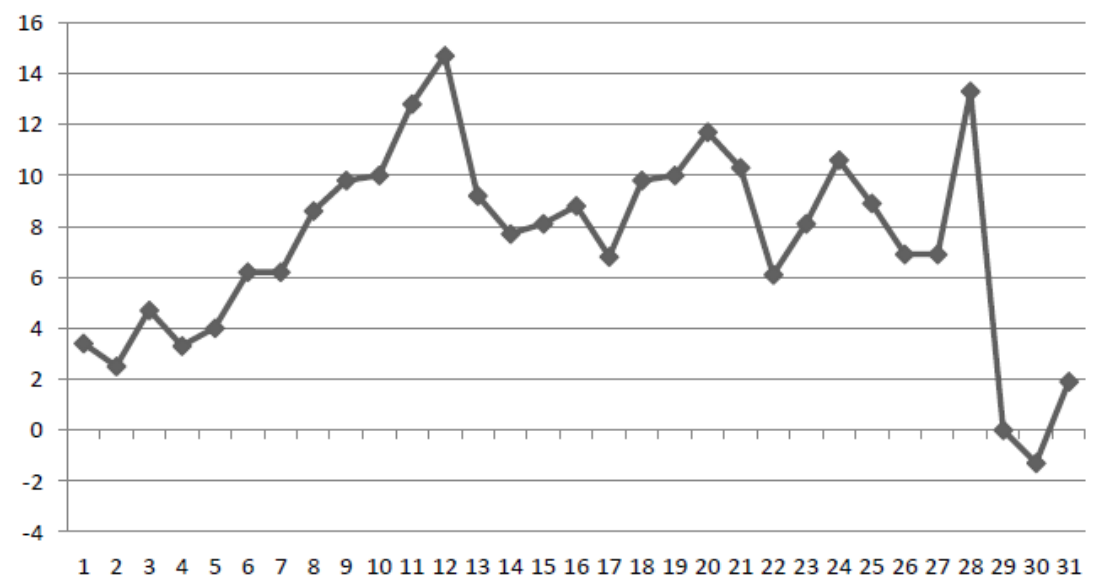

Figure 7. Average temperature for a complete winter month in Porsgrunn ( $\mathrm{y}$-axis shows the temperature in degrees Celsius and $\mathrm{x}$-axis shows the number of days)

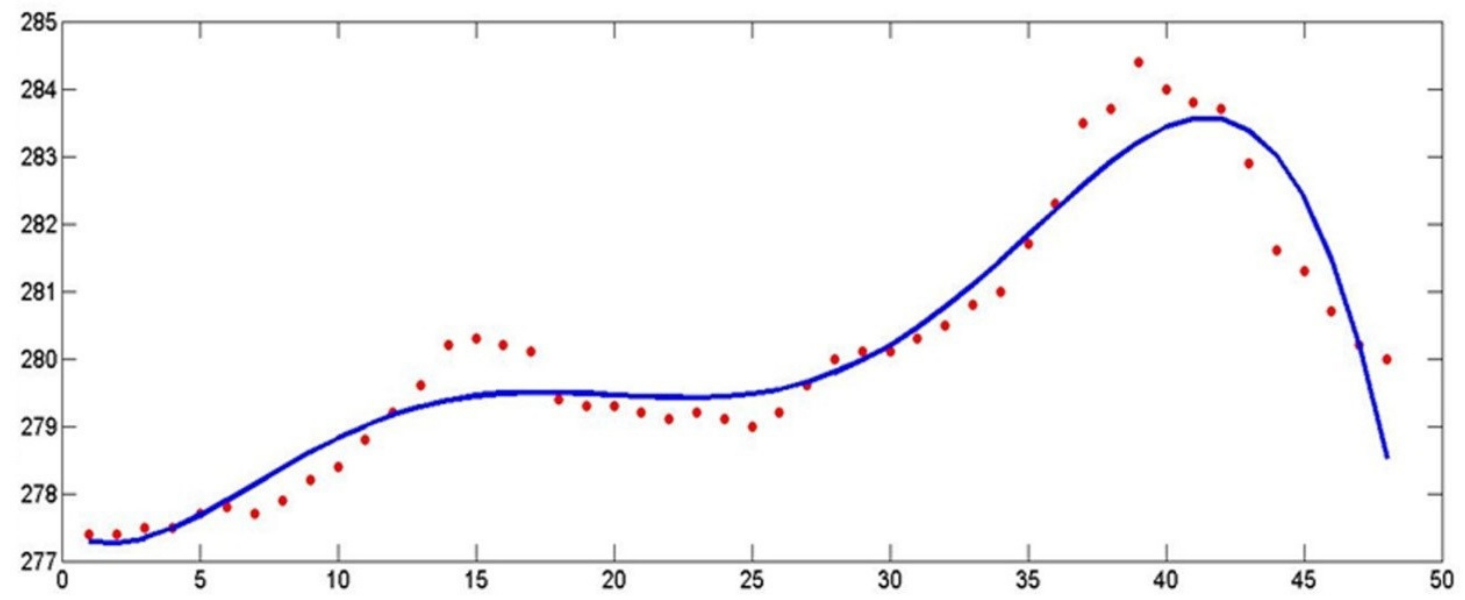

Figure 8. Ambient temperature for two days (y-axis shows the temperature in Kelvin, $\mathrm{x}$-axis shows time in hours, red dots are real data and blue line indicate polynomial order 5)

\section{SIMULATION}

In order to test and simulate the solar system model based on the defined assumptions and the model of the house, MATLAB programme has been used. As it was mentioned, the maximum simulation time has been considered for 48 hours. In order to measure solar radiation and include it in our models, a low cost yet reliably designed Pyranometer has been used [22]. Since this sensor is not able to measure sun radiation for cloudy weather, sun radiation for a complete cloudy day is considered to be $40 \%$ of measured radiation at a particular time of a sunny day. For instance, if there is $400 \mathrm{~W} / \mathrm{m}^{2}$ sun radiation at 11:00 AM of a sunny day, $40 \%$ of this amount is considered for the same time of a cloudy day.

\section{Simulation of the model of the house using solar system}

The goal of this phase is activating the solar system in the house and checking the amount of heat which can be produced by the solar system in the house. Since for the first 6 hours (00:00 until 6:00 AM) there is no sun radiation, an electrical heater of 1,000 W is used to heat the house for these hours and it will be turned off for the remaining 42 hours. Figure 9a shows the temperature of the house in 48 hours using the solar system. The initial air temperature considered is $278 \mathrm{~K}$. As seen in Figure 9a, by using an electrical 
boiler for the first 6 hours, the temperature is increased from $278 \mathrm{~K}$ to $283 \mathrm{~K}$. In order to check the efficiency of the system in terms of heating, it is better to look at critical hours when the ambient temperature has the lowest proportion. At the end of the first day $\left(24^{\text {th }}\right.$ hour), when ambient temperature is around $279.2 \mathrm{~K}$, the temperature of the house reaches 288.2 $\mathrm{K}$ and after the next 48 hours, at the end of the second day, where ambient temperature is $278.5 \mathrm{~K}$, the temperature of the house has a value of $302.8 \mathrm{~K}$, which shows the inside temperature is at comfort level and the house has become warm enough.
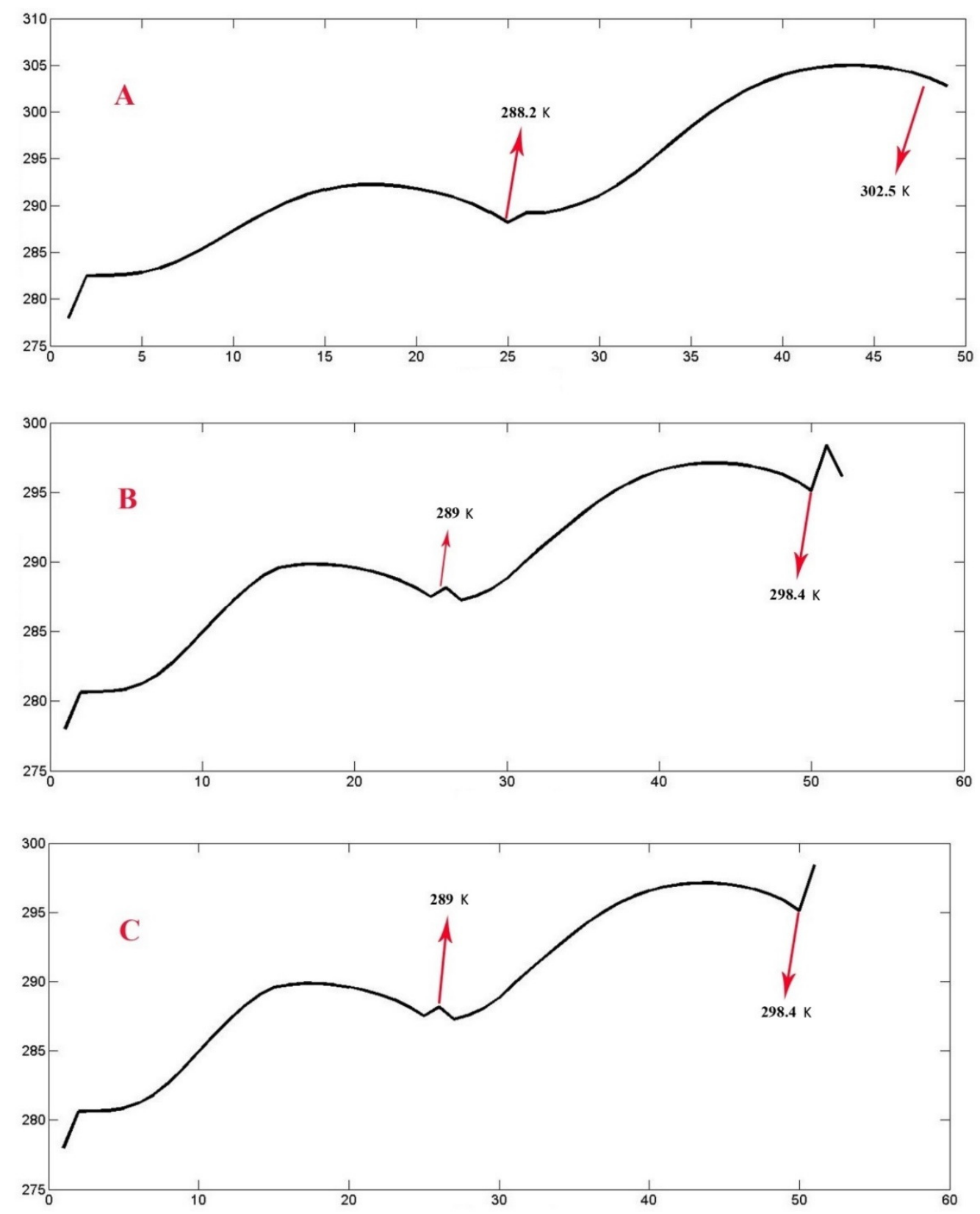

Figure 9. Comparing the temperature of the house for different scenarios (y-axis shows the temperature of the house in Kelvin and $\mathrm{x}$-axis shows time in hours)

\section{Simulation of the model of the house using solar system and PCM}

The only difference of this phase with the previous phase is that here, a PCM has been included into the model to check how it affects the heating process. Again, an electrical heater with 1,000 W is used to heat the house for the first 6 hours, and it will be removed for the remaining 42 hours. Figure $9 \mathrm{~b}$ shows the temperature of the house using the solar system and the PCM on the floor. By using a PCM in this model, the maximum 
temperature of the house in the $48^{\text {th }}$ hour drops to to $295.4 \mathrm{~K}$. Based on the designed model and the considered melting point, during 48 hours the PCM is absorbing heat and it causes to reduce the temperature of the house by around $8 \mathrm{~K}$ and after 48 hours, when the temperature of the house is decreasing, PCM releases the heat to the air in the house, and the maximum temperature of the house reaches $298.4 \mathrm{~K}$, which is an adequate temperature for indoor comfort.

\section{Simulation of the model of the house using solar system PCM and electrical boiler}

In this phase, in addition to the solar system and PCM, an electrical boiler with $2,000 \mathrm{~W}$ is used for the water tank. Figure 9c shows the temperature of the house after applying the electrical source into the model. By looking at critical points $\left(24^{\text {th }}\right.$ hour and $48^{\text {th }}$ hour), it can be seen that the temperature of the house has increased. The house temperature after 24 hours reaches $289 \mathrm{~K}$, which in comparison with the two previous phases, has a higher value ( $7 \mathrm{~K}$ increment), and also after 48 hours, the temperature reaches $297.1 \mathrm{~K}$. The temperature curve has a higher slope and after 12 hours, it reaches $288.9 \mathrm{~K}$. Figure 9 demonstrates different scenarios for the temperature of the house. In this section, a P-controller and a thermostat have been used to turn off the electrical boiler upon reaching the reference temperature which has been set by the user.

\section{Electricity consumption and electricity cost of the system}

As mentioned, one of the main goals of this research is reducing the electricity cost at home by using a solar heating system. The only electricity source used in this system is the electrical boiler applied to the water tank in order to heat up the water when there is no radiation. In order to control the temperature of the house to reach the desired temperature, a control strategy can be used. In this research, it is assumed that the thermostat has a built-in proportional controller and is able to control the temperature of the house based on the reference temperature. The controller decides at what time and which temperature the heaters should be activated in order to reach the desired temperature, and it is important to have a stable temperature by using a controller in the house. Simulated data, like solar irradiance, the temperature of the house, the temperature of the water in the tank and the ambient temperature, are used to figure out a suitable controller which works in parallel with solar heating system and has a higher efficiency in terms of energy consumption and response time.

A proportional controller is a linear feedback control system and is different from an on-off switch system like a bi-metallic domestic thermostat. Proportional controllers are simple to use and tune. Eq. (9) shows the controller output, which is a multiplication product of the error signal and the proportional gain plus bias, where the error signal is the difference value between the reference and the process value:

$$
\begin{gathered}
P_{\text {out }}=K_{c} e(t)+\text { Bias } \\
e(t)=S P-P V
\end{gathered}
$$

where $K_{c}$ is the proportional gain, $P_{\text {out }}$ is the output of the proportional controller and $e(t)$ is the instantaneous process error at time $t . S P$ is the set point and $P V$ is the process variable. Here, the set point for the temperature of the house is assumed $294 \mathrm{~K}$ and the proportional gain is 300 . A bias of $2.5 \mathrm{~kW}$ is considered for the heating system. The initial value for the temperature of the house and the water in the tank is $278 \mathrm{~K}$. Another parameter which is calculated to find energy consumption for the model of the house is electricity cost. Based on statistics of higher electricity costs for households in Norway 2013, a fixed electricity price of $37 \varnothing \mathrm{re} / \mathrm{kWh}$ is considered [24]. Eq. (11) indicates the controller output in terms of heat control inside the house: 


$$
Q_{c}=Q_{0}+K_{c}\left(T_{\text {set }}-T_{\text {air }}\right)
$$

where $Q_{c}$ is the electrical power of the heater, $Q_{0}$ is the initial power value of electrical heater, $K_{c}$ is the proportional gain, $T_{\text {set }}$ is the reference temperature and $T_{\text {air }}$ is the temperature of the air, with reference to eq. (7). Since by using the solar system after 35 hours the temperature of the house reaches $294 \mathrm{~K}$, simulation is done just for 35 hours in order to activate the heaters to achieve the reference temperature. Figure 10 shows the temperature of the house using a proportional controller.

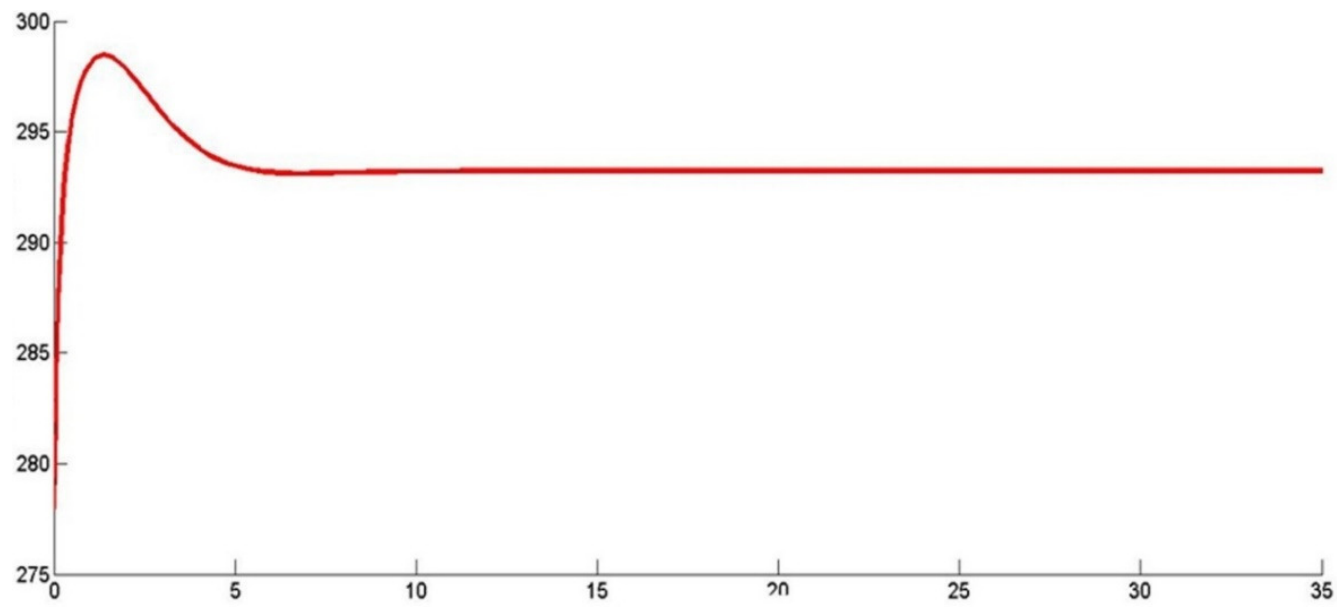

Figure 10. The temperature of the house with using solar system and P-controller (y-axis shows the temperature of the house in Kelvin and $\mathrm{x}$-axis shows time in hours)

As seen in Figure 10, after around 6 hours, the temperature of the house reaches 293.1 K, which is near the set point temperature ( $294 \mathrm{~K}$ ). Figure 11 shows the electricity consumption of the solar system using P-controller, and Figure 12 shows the electricity cost of the system when it works with PCM and electricity at the same time.

As seen in Figure 11, electricity power reaches around 5,000 W within 1.5 hour and it will be constant at $2,700 \mathrm{~W}$ for the rest of the duration, when the temperature of the house is fixed to the set point $(294 \mathrm{~K})$. Figure 12 shows that the electricity cost is fixed to 100 Øre/kWh after 6 hours (Øre is Norway's currency). As seen in Figure 10 to Figure 12, for the first six hours, the electricity cost increases because of the electrical heater in the system until the reference point is reached, and after that, the electricity consumption drops and thanks to it, the electricity cost is reduced at the same time and for the remaining 42 hours, the energy cost has a constant value.

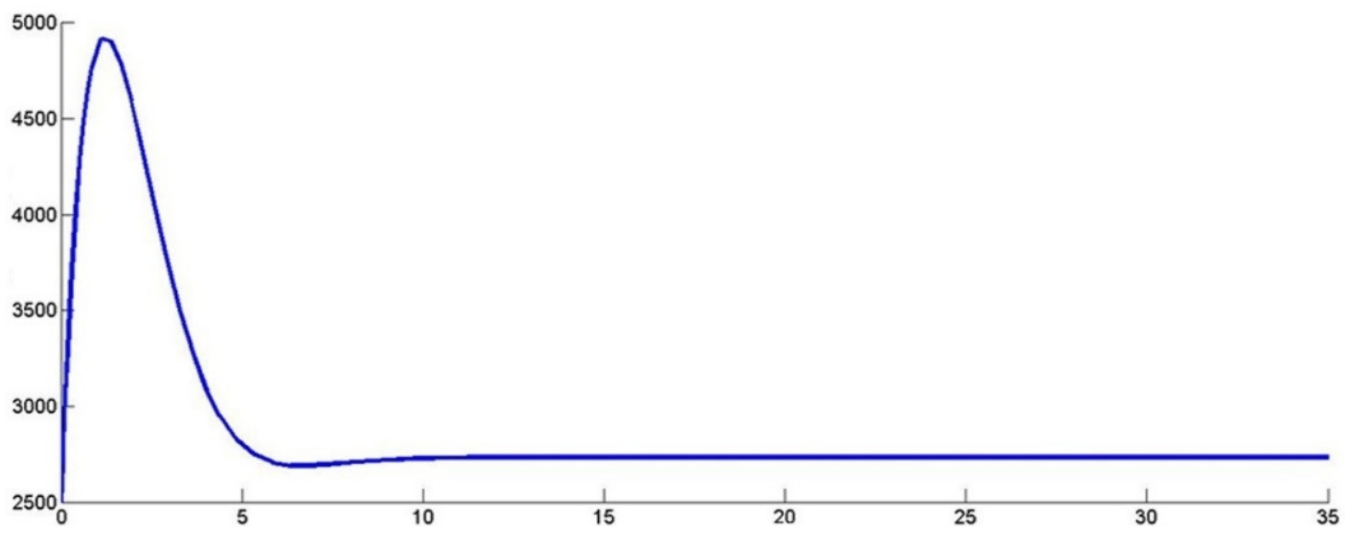

Figure 11. Electricity consumption of the system to reach comfort temperature inside the house (y-axis shows the electricity power in $\mathrm{W}$ and $\mathrm{x}$-axis shows time in hours) 


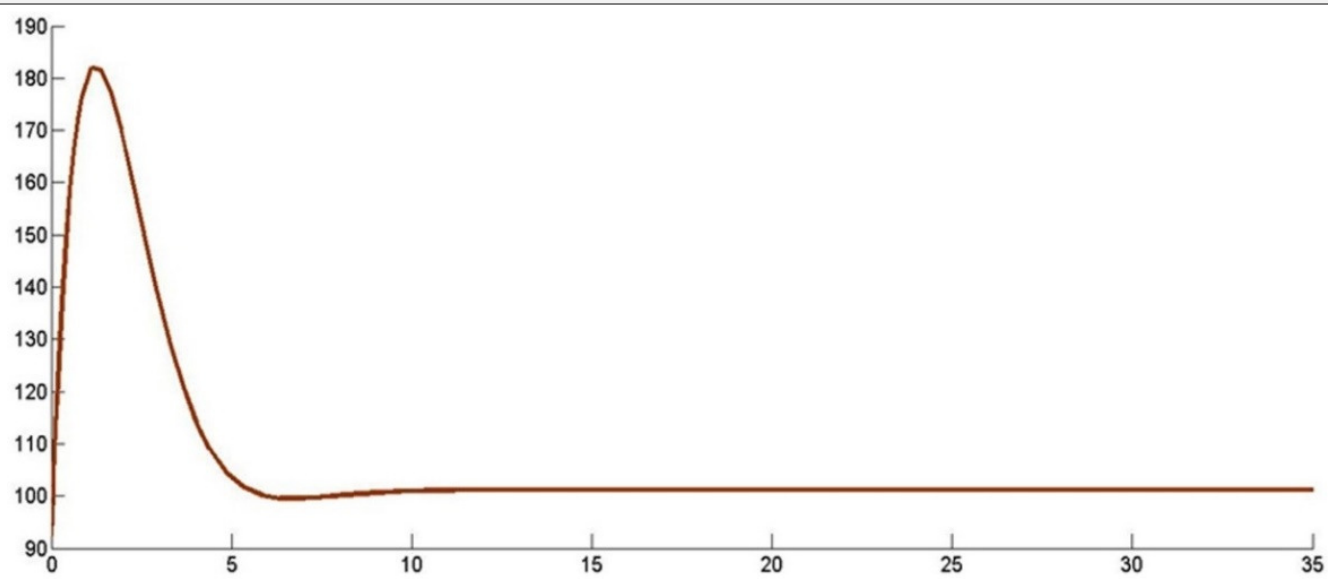

Figure 12. Electricity cost of the house using solar system and electrical boiler (y-axis shows the electricity price in $\varnothing \mathrm{re} / \mathrm{kWh}$ and $\mathrm{x}$-axis shows time in hours)

\section{CONCLUSION}

The results of this research show that a solar heating system which works in parallel with electricity is able to provide a sufficient temperature for a house in the winter time. As all the ambient temperature measurements and radiation measurements have been done in March, which is a winter month in Norway and still the environment temperature is cold enough to use heaters to warm up the house, this system is considered as an efficient heating system. Using the phase change materials in order to have a passive solar building design, an improvement in the inside temperature of the house is seen and after 48 hours, the temperature of the house reaches $24{ }^{\circ} \mathrm{C}$ and subsequently a reduction in terms of electricity consumption is achieved. In this research, the goal was to heat up the PCM during the day time with the help of the Sun when the radiation level and ambient temperature are high enough to melt the PCM and heat release occurs during the night when there is no radiation. This is done to improve the inside temperature of the house and keep it at a stable level, while in the previous study, researchers tried to use electrical power to melt the PCM during the night and release the heat in the day time. Another important parameter in this research is using the water pumps which work with electricity to pump water through under floor pipes and in some previous works, this had been neglected. Another difference in this research in comparison with some projects in the past is that solar photovoltaic energy has not been used for heating purpose and the only parameters which are used to heat up the water are sun radiation and an electrical boiler, which works with urban electricity. One of the goals in this case was reducing the costs of the system. Installing Photovoltaic (PV) panels in this case could increase the costs. It must be noticed that the house in this research is not a complete passive house and PCM's are located just under the floor and not in the windows or walls. By using a proportional controller in the system, it is possible to adjust the temperature to the desirable set point and have a stable temperature. Also, as it was shown, the electricity consumption and cost are remarkably reduced.

\section{ACKNOWLEDGEMENT}

The authors would like to acknowledge University College of Southeast Norway for all support for this work.

\section{NOMENCLATURE}

$\begin{array}{llr}e(t) & \text { instantaneous process error } & {[-]} \\ \dot{H}_{i} & \text { input mass }\end{array}$

$\dot{H}_{i} \quad$ input mass $\quad[\mathrm{kg}]$




\begin{tabular}{llc}
\hline$\dot{H}_{o}$ & output mass & {$[\mathrm{kg}]$} \\
$K_{c}$ & proportional gain & {$[-]$} \\
$\dot{Q}$ & heat amount inside the model & {$[\mathrm{J}]$} \\
$Q_{c}$ & electrical power of the heater & {$[\mathrm{W}]$} \\
$Q_{0}$ & initial value of the electrical heater & {$[\mathrm{W}]$} \\
$P_{\text {out }}$ & output of the proportional controller & {$[-]$} \\
$T_{\text {set }}$ & set point temperature & {$[\mathrm{K}]$} \\
$\dot{W}_{s}$ & shaft work & {$[\mathrm{J}]$}
\end{tabular}

\section{Greek letters}

$\delta$

heat efficiency

\section{Abbreviations}

$\begin{array}{ll}\text { PCM } & \text { Phase Change Material } \\ \text { PV } & \text { Photovoltaic; Process Variable } \\ \text { SP } & \text { Set Point } \\ \text { ST } & \text { Solar Thermal }\end{array}$

\section{REFERENCES}

1. Zheng, P. X. L. and Mao, J., A Low Cost Seasonal Solar Soil Heat Storage System for Greenhouse Heating: Design and Pilot Study, Applied Energy, Vol. 156, pp 213-222, 2015, https://doi.org/10.1016/j.apenergy.2015.07.036

2. Rekstad, J., Meir, M., Murtnes, E. and Dursun, A., A Comparison of the Energy consumption in Two Passive Houses, one with a Solar Heating System and one with an Air-water Heat Pump, Energy and Buildings, Vol. 96, pp 149-161, 2015, https://doi.org/10.1016/j.enbuild.2015.02.059

3. Yoo, J.-H., Evaluation of Solar Hot Water Heating System Applications to High-rise Multi-family Housing Complex based on three Years of System Operation, Energy and Buildings, Vol. 101, pp 54-63, 2015, https://doi.org/10.1016/j.enbuild.2015.04.037

4. Mori, T. and Kawamura, A., Design of Solar Water Heating System for Detached House in Cold Climate Area, Energy Procedia, Vol. 48, pp 1393-1400, 2014, https://doi.org/10.1016/j.egypro.2014.02.157

5. Colclough, S. and McGrath, T., Net Energy Analysis of a Solar Combi System with Seasonal Thermal Energy Store, Applied Energy, Vol. 147, pp 611-616, 2015, https://doi.org/10.1016/j.apenergy.2015.02.088

6. Fraga, C., Mermoud, F., Hollmuller, P., Pampaloni, E. and Lachal, B., Large Solar Assisted Heat Pump Systems in Collective Housing: In-situ Monitoring Results for Summer Season, Energy Procedia, Vol. 48, pp 1086-1095, 2014, https://doi.org/10.1016/j.egypro.2014.02.123

7. Said, T., Taherian, H., Fung, A. and Tse, H., Solar- assisted Space Heating of a Highley Insulated Energy Efficient House, Presented at the International High Performance Building Conference at Purdue University, USA, 2010.

8. Badescu, V., Simulation Analysis for the Active Solar Heating System of a Passive House, Applied Thermal Engineering, Vol. 25, No. 17-18, pp 2754-2763, 2005, https://doi.org/10.1016/j.applthermaleng.2005.02.002

9. Ampatzi, E., Knight, I. and Wiltshire, R., The Potential Contribution of Solar Thermal Collection and Storage Systems to meeting the Energy Requirements of North European Housing, Solar Energy, Vol. 91, pp 402-421, 2013, https://doi.org/10.1016/j.solener.2012.09.008

10. Tamvakidis, S., Firfiris, V. K., Martzopoulou, A., Fragos, V. P. and Kotsopoulos, T. A., Performance Evaluation of a Hybrid Solar Heating System for Farrowing Houses, Energy and Buildings, Vol. 97, pp 162-174, 2015, https://doi.org/10.1016/j.enbuild.2015.04.002 
11. Ahmad, M. W., Eftekhari, M., Steffen, T. and Danjuma, A. M., Investigating the Performance of a Combined Solar System with Heat Pump for Houses, Energy and Buildings, Vol. 63, pp 138-146, 2013, https://doi.org/10.1016/j.enbuild.2013.03.055

12. Zhou, G., Zhang. Y., Performance of a Hybrid Heating System with Thermal Storage using Shape-stabilized Phase-change Material Plates, Applied Energy, Vol. 84, No. 10, pp 1068-1077, 2007, https://doi.org/10.1016/j.apenergy.2006.09.015

13. Kensby, J., Trüschel, A. and Dalenbäck, J.-O., Potential of Residential Buildings as Thermal Energy Storage in District Heating Systems - Results from a Pilot Test, Applied Energy, Vol. 137, pp 773-781, 2015, https://doi.org/10.1016/j.apenergy.2014.07.026

14. Izquierdo, M. and de Agustín-Camacho, P., Solar Heating by Radiant Floor: Experimental Results and Emission Reduction obtained with a Micro Photovoltaic-heat Pump System, Applied Energy, Vol. 147, pp 297-307, 2015, https://doi.org/10.1016/j.apenergy.2015.03.007

15. Doerr, T., Passive Solar Simplified: Easily Design a Truly Green Home for Colorado and the West ( $1^{\text {st }}$ ed.), Lexington, KY: Alitheia Press, c2012, 2012.

16. Kumar, R. and Rosen, M. A., A Critical Review of Photovoltaic-thermal Solar Collectors for Air Heating, Applied Energy, Vol. 88, No. 11, pp 3603-3614, 2011, https://doi.org/10.1016/j.apenergy.2011.04.044

17. Soares, N., Costa, J. J., Gaspar, A. R. and Santos, P., Review of Passive PCM Latent Heat Thermal Energy Storage Systems towards Buildings' Energy Efficiency, Energy and Buildings, Vol. 59, pp 82-103, 2013, https://doi.org/10.1016/j.enbuild.2012.12.042

18. Dubovsky, G. Z. V. and Letan, R., Effect of Windows on Temperature Moderation by a Phase-change Material (PCM) in a Structure in Winter, Energy Conversion and Management, Vol. 87, pp 1324-1331, 2014, https://doi.org/10.1016/j.enconman.2014.04.007

19. Sutterlin, W. R., A Brief Comparison of Ice Packs, Salts, Paraffins and Vegetable-derived Phase change Materials, 2014, http://www.puretemp.com/_literature_131067/A_brief_comparison_of_ice_packs,_salt s,_paraffins_and_vegetable-derived_PCMs, [Accessed: 10-June-2015]

20. Nagano, K., Mochida, T., Takeda, S., Domański, R. and Rebow, M., Thermal Characteristics of Manganese (II) Nitrate Hexahydrate as a Phase change Material for Cooling Systems, Applied Thermal Engineering, Vol. 23, No. 2, pp 229-241, 2003, https://doi.org/10.1016/S1359-4311(02)00161-8

21. Boxwell, M., Solar Electricity Handbook - 2015 Edition: A Simple, Practical Guide to Solar Energy - Designing and Installing Solar PV Systems, Greenstream Publishing, Birmingham, UK, 2015.

22. Medugu, D. W., Burari, F. W. and Abdulazeez, A. A., Construction of a Reliable Model Pyranometer for Irradiance Measurements, African Journal of Biotechnology, Vol. 9, No. 12, pp 1719-1725, 2010, https://doi.org/10.5897/AJB10.030

23. Darling, D., Active Solar Energy System, 2015, http://www.daviddarling.info/encyclopedia/A/AE_active_solar_energy_system.html, [Accessed: 10-July-2015]

24. SSB, Electricity Prices, http://www.ssb.no/en/elkraftpris,

[Accessed: 25-February-2014] 